\title{
ALIENS IN THE SUB-ANTARCTIC - BIOSECURITY AND CLIMATE CHANGE
}

\author{
by Jennie Whinam
}

(with four tables)

\begin{abstract}
Whinam, J. 2009 (11:xii): Aliens in the sub-Antarctic - biosecurity and climate change. Papers and Proceedings of the Royal Society of Tasmania 143(1): 45-51.https://doi.org/10.26749/rstpp.143.2.45 ISSN 0080-4703. Resource Management \& Conservation, Department of Primary Industries, Parks, Water and Environment, GPO 44, Hobart, Tasmania 7001, Australia. Email: Jennie.Whinam@dpiwe.tas.gov.au

Alien species constitute the biggest risk to the integrity of terrestrial sub-Antarctic ecosystems. 'Ihe number of alien species is related t• island size, temperature, human occupancy and visitation. Increasing numbers of tourists and expeditioners, combined with an amelioration in conditions associated with climate change are likely to result in an increasing number of alien species arriving at sub-Antarctic islands, as well as an increase in the distribution of existing alien species. Biosecurity is considered to be the most appropriate to $\bullet$ minimise new introductions and establishment of alien species and to manage existing populations.
\end{abstract}

Key Words: sub-Antarctic, alien species, biosecurity, climate change.

\section{INTRODUCTION}

The aim of biosecurity in the sub-Antarctic is to minimise the risk of accidental introduction of alien species and diseases and to ensure rapid response to incursions if they occur. Different countries use varying degrees of biosecurity, supported by a variety of legislation and management plans.

Alien species are those that occur outside their normal or natural range, either as a direct or indirect result of human activity, or as self-introductions from a site of known human introduction (Parks and Wildlife Service 2006). The impact of alien species ranges from minor transient introductions to substantial loss of biodiversity and ecosystem changes. It is recognised that alien species pose the greatest threat to the integrity of natural ecosystems in the sub-Antarctic (Frenot et al. 2001). The threat of alien species establishing in the sub-Antarctic, as well as the likelihood of alien species present being able to expand their distribution, is considered likely to increase with the ameliorating conditions expected to occur with climate change on islands with depauperate floras and faunas and vacant niches (Bergstrom \& Chown 1999, Chapuis et al. 2004, Frenot et al. 2005, Whinam et al. 2005). Some sub-Antarctic islands are already experiencing increases in air and sea-surface temperatures, with predictions that climate in the region will conrinue to change through the twenty-first century in line with twentieth-century trends (Pendlebury \& Barnes-Keoghan 2007).

Island size, temperature, human occupancy and visitation have been identified as correlates of successful invasions on Southern Ocean islands (Chown et al. 1998). The most obvious impacts of alien species in the sub-Antarctic have been identified as: (i) extensive habitat modification or destruction by grazing vertebrates; (ii) local population reduction or extinction of indigenous bird species by alien predatory vertebrates; (iii) the introduction of new trophic levels (predators) into invertebrate communities where they were previously not present; and (iv) alterations in the levels of competition faced in plant and invertebrate communities (Convey et al. 2006). The type of impact varies with the alien species and the area that it is able to occupy, as well as direct and indirect interactions between impacts.

Biosecurity is considered to be the most effective tool to prevent and manage alien species in the sub-Antarctic. Biosecurity is a pro-active concept, aligned with the preborder, border and post-border continuum, a multilayered approach, with an emphasis on managing risk and border management (Biosecurity Australia, http://www.daff. gov.au/ba). Currently there is no unified approach to biosecurity across the sub-Antarctic, and therefore the aims of biosecurity vary slightly between the management authorities of different nations. The aims stated in the Heard Island Management Plan (Australian Antarctic Division 1995) outline the general intent of sub-Antarctic biosecurity - to ensure that no flora or fauna are introduced into the region as a result of human activity. The plan goes on to say that it is probably not possible to prevent microscopic organisms being introduced but concentrates on macroscopic species.

For biosecurity to be successful, it is necessary for a cultutal change to occur, where biosecurity is regarded as a priority from the highest levels of management and legislation down to the people working in the sub-Antarctic and at the port facilities provisioning the islands. This may be relatively easy with tourists who are "one off" visitors to the area and with new expeditioners, but can take some time with long-term expeditioners, who may resist changes. For example, on Macquarie Island, a compromise was reached where the last two "pet" cats, Felis catus Linnaeus, 1758, were allowed to live out their lives in the early 1990s, but on condition that no further pets would be allowed.

\section{Aliens across the sub-Antarctic}

The number of alien species present varies dramatically across the sub-Antarctic and includes vascular plant species, vertebrates and invertebrates (table 1), microbial groups and diseases, and marine species. Some alien species pose little threat to the conservation of sub-Antarctic islands (e.g., Anthriscus sylvestris Hoffm. on South Georgia) while others greatly modify plant communities (e.g., mammal grazers, or plants reaching dominance in many different areas and 
TABLE 1

Number of alien species of vascular plants, invertebrates and invertebrates on sub-Antarctic islands (from Convey 2008).

\begin{tabular}{lcccccc}
\hline & $\begin{array}{c}\text { South } \\
\text { Georgia }\end{array}$ & $\begin{array}{c}\text { Prince Edward } \\
\text { Islands }\end{array}$ & $\begin{array}{c}\text { Crozet } \\
\text { archipelago }\end{array}$ & $\begin{array}{c}\text { Kerguelen } \\
\text { archipelago }\end{array}$ & $\begin{array}{c}\text { Heard Island } \\
\text { Macquarie } \\
\text { Island }\end{array}$ \\
\hline Vascular plants & 33 & 16 & 59 & 69 & 1 & 3 \\
Invertebrates & 12 & 19 & 14 & 30 & 3 & 28 \\
Vertebrates & 3 & 1 & 6 & 12 & 0 \\
\hline
\end{tabular}

TABLE 2

Alien vertebrate species present on sub-Antarctic islands. ${ }^{1}$

\begin{tabular}{|c|c|c|c|c|c|c|}
\hline Species & $\begin{array}{l}\text { South } \\
\text { Georgia }\end{array}$ & $\begin{array}{l}\text { Prince Edward } \\
\text { Islands }\end{array}$ & $\begin{array}{c}\text { Crozet } \\
\text { archipelago }\end{array}$ & $\begin{array}{l}\text { Kerguelen } \\
\text { archipelago }\end{array}$ & $\begin{array}{l}\text { Heard \& } \\
\text { MacDonald }\end{array}$ & $\begin{array}{l}\text { Macquarie } \\
\text { Island }\end{array}$ \\
\hline Black Rat & & & 1 & 1 & & 1 \\
\hline Brown Rat & 1 & & & & & \\
\hline House Mouse & 1 & 1 & 1 & 1 & & 1 \\
\hline Rabbit & & & 2 & 1 & & 1 \\
\hline Sheep & & & & 1 & & \\
\hline Mouflon & & & & 1 & & \\
\hline Reindeer & 1 & & & 1 & & \\
\hline Cat & & & 1 & 1 & & \\
\hline Salmonid fishes & $0(1)^{2}$ & $0(1)$ & 2 & 8 & & \\
\hline Mallard & & & & & & 1 \\
\hline Starling & & & & & & 1 \\
\hline Red polls & & & & & & 1 \\
\hline $\begin{array}{l}\text { Total alien } \\
\text { vertebrates }\end{array}$ & 3 & 1 & 7 & 12 & 0 & 6 \\
\hline
\end{tabular}

1 From Frenot et al. 2005; Kerguelen fish data from Lésel et al. 1971 and Davaine \& Beall 1997.

2 The numbers in brackets are the number of alien species previously recorded from a sub-Antarctic island, with some numbers currently lower due to eradiation or disappearance.

TABLE 3

Families of alien invertebrate species recorded from sub-Antarctic islands. ${ }^{1}$

\begin{tabular}{|c|c|c|c|c|c|c|}
\hline & $\begin{array}{c}\text { South } \\
\text { Georgia } \\
\end{array}$ & $\begin{array}{c}\text { Prince Edward } \\
\text { Islands } \\
\end{array}$ & $\begin{array}{c}\text { Crozet } \\
\text { archipelago } \\
\end{array}$ & $\begin{array}{c}\text { Kerguelen } \\
\text { archipelago }\end{array}$ & $\begin{array}{l}\text { Heard } \\
\text { Island } \\
\end{array}$ & $\begin{array}{c}\text { Macquarie } \\
\text { Island }\end{array}$ \\
\hline \multicolumn{7}{|c|}{$x_{0}$} \\
\hline Collembola & 2 & 3 & 4 & 5 & 0 & 6 \\
\hline Blattodea & 0 & 1 & 1 & 1 & 0 & 0 \\
\hline Psocoptera & 0 & 0 & 0 & 1 & 0 & 0 \\
\hline Thysanoptera & 0 & 0 & 0 & 0 & 1 & 0 \\
\hline Hemiptera & 2 & 4 & 4 & 5 & 0 & 3 \\
\hline Coleoptera & 2 & 0 & 0 & 2 & 0 & 0 \\
\hline Lepidoptera & 0 & 1 & 0 & 0 & 0 & 0 \\
\hline Siponaptera & 0 & 0 & 0 & 0 & 0 & 1 \\
\hline Diptera & 5 & 6 & 2 & 7 & 0 & 1 \\
\hline Amphipoda & 0 & 0 & 0 & 0 & 0 & 1 \\
\hline Isopoda & 0 & 1 & 0 & 0 & 0 & 1 \\
\hline Acarina & 0 & 0 & 0 & 2 & 1 & 10 \\
\hline Aranea & 1 & 0 & 1 & 3 & 0 & 0 \\
\hline \multicolumn{7}{|l|}{ Phylum } \\
\hline Annelida & 0 & 1 & 2 & 3 & 1 & 4 \\
\hline Mollusca & 0 & 1 & 0 & 1 & 0 & 1 \\
\hline Totals & 12 & 18 & 14 & 30 & 3 & 28 \\
\hline
\end{tabular}

${ }^{1}$ From Frenot et al. 2005, with additional information from H. Dartnall pers. comm. 
habitats (e.g., Taraxacum officinale Wigg on Kerguelen). The alien species life forms that pose conservation and management problems for the sub-Antarctic vary between islands, although the Kerguelen Archipelago has the highest number of alien vascular plants, invertebrates and vertebrates. Some of the alien species on Kerguelen have been introduced as food sources, such as the Reindeer, Rangifer tarandus Smith, 1827, Mouflon, Ovis orientalis orientalis Gmelin, 1774, Sheep, Ovis aries Linnaeus, 1758, and trout and salmon, Oncorhynchus spp., Salmo spp. (table 2). The House Mouse, Mus musculus Linnaeus, 1758 , is the most widespread alien vertebrate species, introduced to several sub-Antarctic islands and impacts upon invertebrates and plants (Convey et al. 2006).

Vertebrate pests (table 2) are generally identified as having the most environmental impacts in the sub-Antarctic, and are generally difficult and expensive to eradicate (LeaderWilliams et al. 1989, Chapuis et al. 1994). For example, on some sub-Antarctic islands (e.g., the eastern part of the Kerguelen Archipelago and Macquarie Island), the combination of rabbit, Oryctolagus cuniculus (Linnaeus, 1758), impacts and recent climatic change is responsible for major changes in vegetation and some massive erosion (Copson \& Whinam 1998, Chapuis et al. 2004, Scott \& Kirkpatrick 2008). Vegetation cover is reduced by rabbit grazing and burrowing, while summer dryness significantly affects the vegetation which has developed largely in the absence of aridity. The resulting significant reduction in plant cover facilitates wind erosion, leading to long-term or irreversible degradation of ecosystems (Whinam et al. 2006, Courchamp et al. 2003).

Established vertebrate pests, such as cats, often have a complex interaction with native species on the island (Copson \& Whinam 2001) and understanding their life cycle and food sources is necessary for successful eradication. For example, multi-year programs using a variety of techniques were necessary to eradicate cats from Marion and Macquarie islands (Bester et al. 2002, Copson 2002). An ambitious Australian-Tasmanian government $\$ 25$ million, five-year program to eradicate rabbits, Black Rat, Rattus rattus (Linnaeus, 1758), and mice is currently being implemented for Macquarie Island (12785 ha). This constitutes the second and third phases of an integrated vertebrate pest eradication program (Parks and Wildlife Service 2007) and follows on from the eradication of rabbits on three islands in the Kerguelen Archipelago in the early 2000s (Lebouvier $\&$ Frenot 2007) and the eradication of rats from Campbell Island (11268 ha) in 2001.

Alien invertebrate species (table 3 ) are generally more difficult to detect, especially as there are limited baseline data available on most invertebrate groups in the subAntarctic (Greenslade 2006, Convey et al. 1999, Crafford et al. 1986). However, they can have severe impacts on sub-Antarctic ecosystems (Hänel \& Chown 1998, Chown \& Language 1994). This is illustrated by the invasion of the carnivorous carabid beetle, Trechisibus antarcticus Dejean, 1831, on South Georgia and the impact it has had on the endemic herbivorous beetle, Hydromedion spasutum (Ernsting et al. 1995). Marine introductions are difficult to detect and have only recently been recognised as a threat to the biodiversity of sub-Antarctic marine ecosystems (Lewis et al. 2003, 2006).

In terms of plant species, Poaceae is the most prominent family with alien species in the sub-Antarctic, with Asteraceae and Caryophyllaceae significant contributors (table 4). While alien Brassicaceae are only present on the Kerguelen and Crozet archipelagos, the risk that species from this family pose

TABLE 4

Families of alien vascular species recorded on sub-Antarctic islands (from Frenot et al. 2005).

\begin{tabular}{|c|c|c|c|c|c|c|}
\hline Family & $\begin{array}{l}\text { South } \\
\text { Georgia }\end{array}$ & $\begin{array}{c}\text { Prince Edward } \\
\text { Islands }\end{array}$ & $\begin{array}{c}\text { Crozet } \\
\text { archipelago }\end{array}$ & $\begin{array}{l}\text { Kerguelen } \\
\text { archipelago }\end{array}$ & $\begin{array}{l}\text { Heard } \\
\text { Island }\end{array}$ & $\begin{array}{c}\text { Macquaric } \\
\text { Island }\end{array}$ \\
\hline Apiaceae & 1 & 0 & 0 & 0 & 0 & 0 \\
\hline Asteraceae* & 5 & 1 & 12 & 10 & 0 & 0 \\
\hline Boraginaceae & 0 & 0 & 0 & 1 & 0 & 0 \\
\hline Brassicaceae & 0 & $\mathbf{0}$ & 4 & 7 & 0 & 0 \\
\hline Campanulaceae & 1 & 0 & 0 & 0 & 0 & 0 \\
\hline Caryophyllaceae & 2 & 5 & 5 & 5 & 0 & 2 \\
\hline Chenopodiaceae & 0 & 0 & 0 & 1 & 0 & 0 \\
\hline Ericaceae & 2 & 0 & 2 & 0 & 0 & 0 \\
\hline Fabaceae & 2 & 0 & 3 & 3 & 0 & 0 \\
\hline Hypericaceae & 1 & 0 & 1 & 0 & 0 & 0 \\
\hline Onagraceae & 0 & 0 & 1 & 1 & 0 & 0 \\
\hline Oxalidaceae & 0 & 0 & 1 & 1. & 0 & 0 \\
\hline Plantaginaceae & 0 & 1 & 1 & 1 & 0 & 0 \\
\hline Polygonaceae & 1 & 1 & 3 & 3 & 0 & 0 \\
\hline Primulaceae & 0 & 0 & 1 & 0 & 0 & 0 \\
\hline Ranunculaceae & 2 & 0 & 1 & 1 & 0 & 0 \\
\hline Rubiaceae & 0 & 0 & 4 & 0 & 0 & 0 \\
\hline Scrophullariaceae & 0 & 0 & 1 & 0 & 0 & 0 \\
\hline Cyperaceae & 2 & 0 & 0 & 0 & 0 & 0 \\
\hline Juncaceae & 1 & 0 & 3 & 3 & 0 & 0 \\
\hline Poaceae & 12 & 7 & 15 & 31 & 1 & 1 \\
\hline Woodsiaceae & 1 & 0 & 1 & 1 & 0 & 0 \\
\hline Total & 33 & 15 & 59 & 69 & 1 & 3 \\
\hline
\end{tabular}

* Families that are most represented are highlighted in bold. 
to the native flora of the region has been recognised, with fresh brassica vegetables banned from Macquarie and Heard islands, and recently from the French sub-Antarctic islands. This is primarily due to the threat that such Brassicaceae may pose to the megaherb Pringlea antiscorbutica Hook. f. and other native plant species through associated diseases and pests. Most of the higher plants established in the sub-Antarctic belong to common and widely distributed families that are often invasive at a global scale (Pysek 1998).

Alien species have been introduced to sub-Antarctic islands since humans explored the region, with the risk of introductions intensifying with increases in travel to the sub-Antarctic and between islands. There are data on the first record of alien plants for some sub-Antarctic islands, such as the French islands (Frenot et al. 2001) and for the Prince Edward Islands (Gremmen \& Smith 1999). Some of the alien species present have been accidentally introduced during visits to the islands, while others have been intentionally introduced either as a food source (such as rabbits) or to be utilised (e.g., cats to control rodents or as pets). Some species are relatively recent incursions, such as Anthoxanthum odoratum L. on Macquarie Island, which was found beside a walking track in 1978 and removed in 1989 (Copson \& Whinam 2001). Some species have reappeared after either absence or eradication (Gremmen \& Smith 1999). Other alien species, such as Poa annua L., are well established across the sub-Antarctic.

\section{Vectors and risks}

There is a link between alien species numbers and the number of human visitors over the past 200 years (Chown et al. 1998) and climate matching (Frenot etal.2008). The sub-Antarctic has a long history of visitors commencing with whalers and sealers, and more recently, tourists and expeditioners. Currently, over 40000 people travel to the Antarctic each year. Of the eight sub-Antarctic island groups, six are regularly visited by expeditioners and tourists (South Georgia, Prince Edward Islands, Crozet Islands, Kerguelen, Macquarie and Heard islands). There has been an increase in visits to the sub-Antarctic by tourists and independent adventurers in recent decades (International Association of Antarctic Tour Operators 2002). There is often much movement by Antarctic scientists and support staff within the area with many visiting other high-latitude or high-altitude areas in the year prior to travelling to the sub-Antarctic, which increases the risk of introducing propagules likely to successfully establish on the islands (Whinam et al. 2005). There is also the risk of transferring biota indigenous to one part of the sub-Antarctic to another, especially as these species are already adapted to the environmental conditions (Convey 2008).

A risk assessment of cargo, food and expeditioners in transit to the sub-Antarctic found that cargo containers, clothing, machinery, boats and some cargo goods posed a high risk as vectors for introducing alien species (Whinam et al. 2005). Equipment identified as high-risk vectors included equipment cases, day packs and the cuffs and Velcro R closures of outer clothing (Whinam et al. 2005).

\section{Aliens in Antarctica program}

Aliens in Antarctica is an international program involving eight countries endorsed by the Scientific Committee on Antarctic Research (SCAR) as part of the 2007/08 Internarional Polar Year (IPY). It is a component of SCAR's
Evolution and Biodiversity in the Antarctic Science Program (EBA). This project follows on from previous work indicating that people are vectors in inadvertently transporting alien species into the Antarctic region (Lee \& Chown 2009, Whinam et al. 2005, Gaston et al. 2003)

The Aliens in Antarctica program assessed the propagule load carried by people on over 40 Antarctic voyages and/or flights into the Antarctic and sub-Antarctic islands during the 2007/08 summer (htcp://www.ipy.org/index.php?/ipy/ detail/aliens_in_antarctica/). Expeditioners' outer clothing and equipment was inspected for propagules. Samples were collected and identified to the lowest taxonomic level possible and using scaling- up procedures total propagule loads will be assessed. Seeds from over 300 taxa have been collected with boots, backpacks and camera bags appearing to be the main items carrying propagules. National personnel were in general carrying more seeds than tourist or ship crew (IPY Aliens in Antarctica unpublished data - D.M. Begstrom pers. comm.).

Recent travel histories of expeditioners were also recorded, to assess potential sources of propagules. The significance of this element of the project is that propagules from cold areas such as the Arctic will have a greater chance of establishing in the Antarctic than those from warmer ecosystems.

While various countries are at different stages of adopring biosecurity strategies, the risks, vectors and possible management strategies are similar across the sub-Antarctic. It will be necessary for international collaboration to minimise the risk of further introductions from home ports to the sub-Antarctic, as well as accidental island-to-island arrivals. The results of work to date indicate that the most effective way to minimise introductions will be to have uniform policies where possible and to treat the biosecurity risks posed by tourists, expeditioners and adventurers equally.

There has been significant progress in some countries, as data highlighting high-risk areas has become available. For example, the French sub-Antarctic islands were granted the status of Nature Reserve in 2006, which gives the islands greater protection for the environment and biota, with management plans expected to be in place by 2010 (Lebouvier \& Frenot 2007). Some management actions relating to biosecurity have already been initiated. The French management authorities, Terres Australes et Antarctiques Francaises (TAAF) with the French Polar Institute (IPEV) have ceased transporting fresh cabbages to the sub-Antarctic after these were found to carry a high number of invertebrates (Lebouvier \& Whinam unpubl. data). In addition, the French are dismantling glasshouses on Îles Amsterdam and Crozet, after a high number of alien invertebrates and plant species were recorded (Lebouvier $\&$ Whinam unpubl. data). The number of vegetable and flower gardens on Île Amsterdam are also being reduced. These have been rapid adaptive management changes in response to data recently collected.

\section{Threats to native species}

The threat that disease poses to Antarctic wildlife has been recognised at an Antarctic Treaty Consultative Meeting, which led to a "Workshop on Diseases of Antarctic Wildlife" in 1998. The workshop recognised that there was a significant risk of the introduction of disease into Antarctic wildlife species and that should it occur the consequences are likely to be serious and a response will be required (Kerry et al. 1999).

Examples included serological evidence for exposure of 
Adélie, Pygoscelis adeliae (Hombron \& Jacquinot, 1841), and Emperor penguins, Aptenodytes forsteri Gray, 1844, at some locations near Mawson to Infectious Bursal Disease Virus (IBDV). This virus causes serious disease in poultry. The presence of viruses and diseases highlights the increasing risk of disease being introduced into the fauna because of the increase in the numbers of people travelling to and within Antarctica (Kerry et al. 1999).

The milder climate associated with sub-Antarctic islands means that arthropod vectors of infectious disease such as ticks and fleas are likely to be present and are able to complete their life cycle. It is possible therefore that disease may be introduced into the wildlife of these islands more readily than to Antarctica if ticks and fleas carrying the disease are accidentally introduced and that they in turn may also play a role in the transmission of disease into Antarctic wildlife (Kerry et al. 1999).

Human activity in the sub-Antarctic could be the cause of disease outbreaks by a number of direct and indirect mechanisms. People could act as vectors for infectious agents, either by bringing non-indigenous pathogens into the region or by translocating indigenous pathogens (Frenot et al. 2008). Avian Paramyxoviruses (APMV) and antibodies to Newcastle Disease (NDV) have been reported from Macquarie Island Royal Penguins, Eudyptes schlegeli (Finch, 1876) (Morgan \& Westbury 1981). In addition, stress caused by human activity could reduce immunity, increase pathogenicity and could cause the expression of a disease that might otherwise not have revealed itself (Kerry et al. 1999). However, humans are not the only mechanism for disease incursion to the sub-Antarctic. New diseases could be carried to the continent by migratory species and by atmospheric events.

An example of species affected by disease includes the two species of albatross breeding on Île Amsterdam. The Amsterdam Albatross Diomedea amsterdamensis, Roux, Jouventin, Mougin, Stahl \& Weimerskirch, 1983, is listed as critically endangered, and the Indian Yellow-nosed Albatross, Thalassarche carteri (Mathews, 1912) listed as vulnerable. A combination of factors is thought to have contributed to their decline, including degradation of habitat due to cattle, Bos taurus Linnaeus, 1758 predation by feral cats, longline fishing and susceptibility to diseases such as Avian Cholera (Pasturella multocida) and Erysipelothrix rhusiopathidae (Weimerskirch 2004, Birdlife International 2009).

\section{Climate change, a new challenge for biosecurity}

Both the direct and indirect impacts of climate change are likely to influence the number of alien species present in the sub-Antarctic and their impacts. Glacial retreat is an indicator of climate change (Pendlebury \& Barnes-Keoghan 2007) and offers the prospect of large areas of relatively fertile, newly disturbed ground being available for colonisation by both native and alien species. Many alien species that are becoming widespread in the sub-Antarctic, such as Poa annua, have characteristics that can give them an advantage in establishing in these conditions.

Propagules of plant species that have previously arrived in the sub-Antarctic are more likely to be able to germinate and colonise in the changing and ongoing predicted ameliorating conditions (Pendlebury \& Barnes-Keoghan 2007. In the Austral summer of 2004/05, we observed Poa annua colonising newly available ground immediately in front of the retreating Glacier Ampère at La Mortadelle, Îles Kerguelen (see also Frenot et al. 1998). Similarly, P. annua has colonised previously glaciated ground near Winston Lagoon on the south coast of Heard Island (Scott 1989).

Another likely result of a more favourable climare is that alien species that currently exist on sub-Antarctic islands are likely to be able to expand their presence. An example of this is Taraxacum offcinale on Îles Kerguelen. This species previously occurred in small numbers on the coastal slopes on Île Australia, downwind of Île Longue, where sheep are grazed. By the time of our visit in 2004/05, this weedy daisy was the dominant flower on the coastal slopes on Île Australia and was present further inland. Rumex acetosella L. was present in small numbers around the main station on Marion Island for many years. However, with a more favourable climate it has now spread further along the island and is altering the ecosystems of some peatlands and wetlands (S.L. Chown pers. comm.). Poa annua has expanded its range (Scott \& Kirkpatrick 2005) northwards on Heard Island to land deglaciated by the retreat of the Stephenson Glacier (Kiernan \& McConnell 2002).

It is acknowledged that new diseases, weeds and pests are likely to be able to colonise sub-Antarctic islands in ameliorating weather conditions (Frenot et al. 2005, Bergstrom \& Chown 1999, Chown \& Language 1994). For example, the introduced fungus Albugo candida Kuntze probably transferred from fresh vegetables to infecting stands of Kerguelen Cabbage (Pringlea antiscorbutica Hook. f.) on Îles Kerguelen (Frenot et al. 2008). We do not know which species or diseases are likely to appear, and so the only real management option is to have stringent biosecurity measures in place to minimise the risk of these arriving, be able to identify them shortly after arrival if this does happen, and be able to take the necessary management actions, such as eradication, native species protection or control. Baseline knowledge is essential to evaluate and monitor the impacts of alien species on sub-Antarctic environments (Walton $\&$ Shears 1994), especially in relation to identifying appropriate management responses and assessing the efficacy of restoration programs.

In addition to the problems that managing alien species and diseases pose in the face of climate change, there are also likely to be changes in the balance of native species. For example, a combination of apparently drier conditions on Macquarie Island combined with a massive number of rabbits, estimated to be more than 100000 (Parks and Wildlife Service 2008), has led to the less palatable Acaena magellanica Lam. becoming dominant over large areas. A similar situation has been observed on Grande Terre (Kerguelen), where $A$. magellanica now forms "nearly monospecific heathlands" (Lebouvier \& Frenot 2007, p. 25). The density of the cover will make it difficult for other native, more palatable species to re-establish when rabbit numbers are reduced.

There is also the likelihood that species will be able to "move" to occupy other habitats as climate conditions ameliorate and/or as barriers disappear. For example, as the glaciers retreat on South Georgia, Reindeer have been able to move to new areas which were previously free of these grazers, and of their environmental impacts (Moen \& MacAlister 1994). The Sphagnum mires of high conservation value in the high-altitude calderas on Île Amsterdam are currently relatively free of weed species (Whinam \& Lebouvier unpubl. data). However, there is a number of alien plant species that occur at lower altitudes on the island that are 
likely to be able to colonise these higher altitude sites in future, if conditions become suitable for an altitudinal shift.

\section{Biosecurity and the future}

It is clear, that for the sub-Antarctic to be protected from the accidental introduction of alien species, the management authorities in all countries involved will have to plan for the unexpected. Despite precautions, there are likely to be many more unforseen disease, weed and invertebrate incursions with increasing numbers of visitors and biosecurity management must be robust to prevent their arrival. There is a need to identify their presence and take management actions to remove or manage their presence. In addition to increased visitor numbers, the direct and indirect impacts of climate change have implications for the management of biosecurity. Management plans for sub-Antarctic islands, such as for Prince Edward and Macquarie islands (DEAT 1996, Parks \& Wildlife Service 2006), highlight the importance of biosecurity in the light of climate change predictions.

Biosecurity will need to be afforded greater priority in sub-Antarctic management - resources will be required for ensuring alien species do not depart ports/airports, that rigorous checking occurs en route to the sub-Antarctic, that there is appropriate expertise available to identify arrival of alien species and that management responses exist. If incursions do occur, then rapid and effective response will be essential, especially as climate conditions become more conducive to new alien species establishing and expanding in the sub-Antarctic. For example, in December 2008, widespread dieback of the Macquarie Island endemic cushion plant, Azorella macquariensis Orchard, was reported (Bergstrom unpubl. data). The dieback has spread rapidly and, by June 2009, surveys by Parks and Wildlife Service rangers showed that dieback was present over all of Macquarie Island, including areas that are rarely visited. Samples collected have been analysed and have not shown evidence of pathogens. However, root material needs to be collected during the next shipping season for pathogenic analysis. Some seed was collected in March 2009 and it is planned to collect fresh material for tissue culture during the next shipping season. Obviously, identification of causal factors for this widespread dieback is necessary for an effective management response. In the meantime, biosecurity precautions have been instigated on personnel travelling on Macquarie Island, as well as expeditioners and equipment exiting the island.

The approach to sub-Antarctic biosecurity has been piecemeal to date, decided and managed by individual nations. The movement of tourists and expeditioners between sub-Antarctic islands and Antarctica indicates that this should change to a co-ordinated international approach. The international collaboration that at present exists in relation to sub-Antarctic biosecurity will have to be strengthened possibly through an international agreement similar to the Antarctic Treaty - to ensure appropriate biosecurity across the region, targeting tourists, adventurers, expeditioners and cargo.

\section{ACKNOWLEDGEMENTS}

I would like to thank Yves Frenot, Marc Lebouvier and Patricia Selkirk for their interesting discussions in the field and subsequently on alien species, biosecurity and climate change. Herbert Dartnall kindly assisted with alien invertebrate taxonomy. Niek Gremmen provided useful comments on the manuscript. I gratefully acknowledge the logistic and technical support provided by the Australian Antarctic Division and the French Polar Institute (IPEV).

\section{REFERENCES}

Australian Antarctic Division 1995: Heard Island Wilderness Reserve Management Plan: 60 pp.

Bergstrom, D.M. \& Chown, S.L. 1999: Life at the front: history, ecology and change on southern ocean islands. Trends in Ecology and Evolution 14: 472-477.

Bester, M.N., Bloomer, J.P., Van Aarde, R.J., Erasmus, B.H., Van Rensburg, P.J.J., Skinner J.D., Howell, P.G. \& Naude, T.W. 2002: A revicw of the successful eradication of feral cats from sub-Antarctic Marion Island, Southern Indian Ocean. South African Journal of Wildlife Research 32: 65-73.

Biosecurity Australia 2009: http://www.daff.gov.au/ba accessed on 4 August 2009.

Birdlife International 2009: http://www.birdlife.org/ datazone/species/index.html?action $=S p c H T M D e t a i l s$. asp\&sid $=3953 \& \mathrm{~m}=0$ accessed on 4 August 2009.

Chapuis, J.L., Bousses, P. 8 c Barnaud, G. 1994: Alien mammals, impacts and management in the French subantarctic islands. Biological Conservation 67: 97-104.

Chapuis, J.L., Frenot, Y. \& Lebouvier, M. 2004: Recovery of native plant communities after eradication of rabbits from the subantarctic les Kerguelen, and influence of climate change. Biological Conservation 117: 167-179.

Chown, S.L., Gremmen, N.J.M. \& Gaston, K.J. 1998: Ecological biogeography of Southern islands: species-area relationships, human impacts and conservation. American Naturalist 152: 562-575.

Chown, S.L. \& Language, K. 1994: Recently established Diptera and Lepidoptera on sub-Antarctic Marion Island. African Entomology B2: 57-60.

Convey, P. 2008: Non-native species in Antarctic terrestrial and freshwater environments: presence, sources, impacts and predictions. In Rogan-Finnemore, M. (ed.): Non-native Species in the Antarctic Proceedings. Gateway Antarctica Special Publication Series, No. 0801 97-130. place of publication

Convey, P. Frenot, Y., Gremmen, N. \& Bergstrom D.M. 2006: Biological Invasions. In Bergstrom, D.M., Convey, P. \& Huiskes A.H.L. (eds): Trends in Antarctic Terrestrial and Limnetic Ecosystems: Antarctica as a Global Indicator. Kluwer Academic Publishers 193-220. place of publication

Convey, P., Greenslade, P., Arnold, R.J. \& Block, W. 1999: Collembola of sub-Antarctic South Georgia. Polar Biology 22: 1-6.

Copson, G.R. 2002: Integrated Vertebrate Pest Management on Subantarctic Macquarie Island 1997-2002. Final Report for Natural Heritage Trust, Department of Primary Industries, Water and Environment, Hobart 37 pp.

Copson, G. \& Whinam, J. 2001: Review of ecological restoration programs on sub-Antarctic Macquarie Island: pest management progress and future directions. Ecological Management and Restoration 2(2): 129-138.

Copson, G. \& Whinam, J. 1998: Response of vegetation on subantarctic Macquarie Island to reduced rabbit grazing. Australian Journal of Botany 46: 15-24. 
Courchamp, F., Chapuis, J.-L. \& Pascal, M. 2003: Mammal invaders on islands: impact, control and control impact, Biological Reviews 78: 347-383.

Crafford, J.E., Scholtz, C.H. \& Chown, S.L. 1986: The insects of subantarcic Marion and Prince Edward Islands; with a bibliography of entomology of the Kerguelen biogeographical province. South African Journal of Antarctic Research 16: 41-84.

Davaine, P. \& Beall, E. 1997 : Introduction de salmonidés en milieu vierge (îles Kerguelen, subantarctique) : Enjeux, résultats, perspectives. Bulletin Francais De La Pêche Et De La Pisciculture, 93-110.

DEAT 1996: Prince Edward Islands Management Plan. Compiled by the Prince Edward Islands Management Plan Working Group and issued by DEAT Directorate Antarctica and Islands, Pretoria, South Africa.

Ernsting, G., Block, W., MacAlister, H. \& Todd, C. 1995: The invasion of the carnivorous carabid beetle Trechisibus antarcticus on South Georgia (sub-Antarctic) and its effect on the endemic herbivorous beetle Hydromedion spasutum. Oecologia 103: 34-42.

Frenot, Y., Gloaguen, J.C., Cannavacciuolo, M. \& Bellido, A. 1998: Primary succession on glacier forelands in the subantarctic Kerguelen Islands. Journal of Vegetation Science 9: 75-84.

Frenot, Y., Gloaguen, J.C., Masse, L. \& Lebouvier, M. 2001: Human activities, ecosystem disturbances and plant invasions in subantarctic Crozet, Kerguelen and Amsterdam Islands. Biological Conservation 101: 33-50.

Frenot, Y., Chown, S.L., Whinam, J., Selkirk, P.M., Convey, P., Skotnicki, M. \& Bergstrom, D.M. 2005: Biological invasions in the Antarctic: extent, impacts and implications. Biological Reviews 80: 45-72.

Frenot, Y., Convey, P., Lebouvier, M., Chown, S.L., Whinam, J., Selkirk, P.M., Skotnicki, M. \& Bergstrom, D.M. 2008: Antarctic and subantarctic biological invasions: sources, extents, impacts and implications. In Rogan-Finnemore, M. (ed.): Non-native Species in the Antarctic Proceedings. Gateway Antarctica Special Publication Series, No. 0801: 53-96. place of publication

Gaston, K., Jones, A., Hanel, C. \& Chown, S. 2003: Rates of species introduced to a remote oceanic island. Proceedings of the Royal Society of London. B. Biological Sciences 270: 1091-1098.

Greenslade, P. 2006: The Invertebrates of Macquarie Island. Australian Antarctic Division, Kingston: 344 pp.

Gremmen, N.J.M. \& Smith, V.R. 1999: New records of alien vascular plants from Marion and Prince Edward Islands, sub-Antarctic. Polar Biology 21: 401-409.

Hänel, C. \& Chown, S.L. 1998: The impact of a small, alien macro-invertebrate on a sub-Antarctic terrestrial ecosystem: Limnophyes minimus Meigen (Diptera, Chironomidae) at Marion Island. Polar Biology 20: 99-106.

International Association of Antarctica Tour Operators (IAATO), 2002. http://www.IAATO.org. accessed 4 August 2009.

Kerry, K.R., Riddle, M.J. \& Clarke, J. 1999: Diseases of Antarctic wildlife: A report for the Scientific Committee on Antarctic Research and the Council of Managers of National Antarctic Programs. 1-104.

Kiernan, K. \& McConnell, A. 2002: Glacier retreat and meltlake expansion at Stephenson Glacier, Heard Island World Heritage Area. Polar Record 38: 297-308.

Leader-Williams, N., Walton, D.W.H. \& Prince, P.A. 1989 . Introduced Reindeer on South Georgia. A management dilemma. Biological Conservation 47: 1-11.

Lebouvier, M. \& Frenot, Y. 2007: Conservation and management in the French sub-Antarctic islands and surrounding seas. Papers and Proceedings of the Royal Society of Tasmania 141(1): 23-28.
Lee, J. \& Chown, S. 2009. Quantifying the propagule load associated with the construction of an Antarctic research station. Antarctic Science 21: 471-475. doi:10.1017/ S0954102009990162

Lewis, P.N., Bergstrom, D.M. \& Whinam, J. 2006: Barging in: a temperate marine community travels to the subantarctic. Biological Invasions (2006): 1-9.

Lewis, P.N., Hewitt, C.L., Riddle, M. \& McMinn, A. 2003: Marine introductions in the Southern Ocean: an unrecognised hazard to biodiversity. Marine Pollution Bulletin 46: 213-223.

Lésel, R., Thérézien, Y. \& Vibert, R. 1971 : Introduction de salmonidés aux Îles Kerguelen: Premiers résultats et observations préliminaires. Annales d'Hydrobiologie 2 : 275-304.

Moen,J. \& MacAlister, H. 1994: Continued range expansion of introduced reindeer on South Georgia. Polar Biology 14: 459-462.

Morgan, I.R. \& Westbury, H.A. 1981: Virological studies of Adelie penguins (Pygoscelis adeliae) in Antarctica. Avian Diseases 25: 1019-1026

Parks \& Wildlife Service 2008: Macquarie Island Rabbit and Rodent Eradication Plan notesheet, http://wwww.parks.tas. gov.au/file.aspx?id=8208 accessed 4 August 2009.

Parks \& Wildlife Service 2007: Plan for the Eradication of Rabbits and Rodents on Subantarctic Macquarie Island. Parks and Wildlife Service, Department of Tourism, Arts and the Environment, Hobart: 30 pp.

Parks \& Wildlife Service 2006: Macquarie Island Nature Reserve and World Heritage Area Management Plan. Parks and Wildlife Service, Department of Tourism, Arts and the Environment, Hobart: 177 Pp.

Pendlebury, S.F. \& Barnes-Keoghan, I.P. 2007: Climate and climate change in the sub-antarctic. Papers and Proceedings of the Royal Society of Tasmania 141: 67-81.

Pysek, P. 1998: Is there a taxonomic pattern to plant invasions? Oikos 82: 282-294.

Scott, J.J. 1989: New records of vascular plants from Heard Island. Polar Record 25: 37-42.

Scott, J.J. \& Kirkpatrick, J.B. 2008: Rabbits, landslips and vegetation change on the coastal slopes of subantarctic Macquarie Island, 1980-2007: implications for management. Polar Biology 31: 409-419.

Scott, J.J. \& Kirkpatrick, J.B. 2005: Changes in subantarctic Heard Island vegetation at sites occupied by Poa annua, 1987-2000. Arctic, Antarctic and Alpine Research 37: 366-371.

Walton, D.W.H. \& Shears, J. 1994: The need for environmental monitoring in Antarctica - baselines, environmental impact assessments, accidents and footprints, International journal of Environmental Analytical Chemistry 55: 77-90.

Weimerskirch H. 2004. Diseases threaten Southern Ocean albatrosses. Polar Biology 27: 374-379.

Whinam, J., Chilcott, N. \& Bergstrom D.M. 2005: Subantarctic hitchhikers: Expeditioners as vectors for the introduction of alien organisms. Biological Conservation 121: 207-219.

Whinam, J., Copson, G. \& Chapuis, J.-L. 2006: Subantarctic terrestrial conservation and management. In Bergstrom, D.M., Convey, P. \& Huiskes, A.H.L. (eds): Trends in Antarctic Terrestrial and Limnetic Ecosystems. Springer, Dordrecht: 297-316.

(accepted 1 September 2009) 